\title{
IMP3 can predict aggressive behaviour of lung adenocarcinoma
}

Renata Beljan Perak', Merica Glavina Durdov ${ }^{1 *}$, Vesna Capkun², Veljka Ivcevic ${ }^{3}$, Antonia Pavlovic ${ }^{1}$, Violeta Soljic ${ }^{4}$ and Mari Peric ${ }^{5}$

\begin{abstract}
Background: Lung cancer most often presents as an inoperable tumour and the diagnosis is usually performed on a small biopsy/cytology specimen. In the group of non small cell lung cancer - not otherwise specified, adenocarcinoma phenotype can be determined immunohistochemically using TTF-1 and Napsin A. Expression of oncofetal protein IMP3 in human cancer is associated with poor differentiation and aggressive behaviour. In the present study expression of IMP3 was correlated with expression of TTF-1 and Napsin A, histological subtype and clinical stage of lung adenocarcinoma. We were interested whether distant metastases are associated with IMP3 overexpression, regardless of the histologic subtype of adenocarcinoma.
\end{abstract}

Methods: In retrospective study, consecutive series of 105 patients with advanced lung adenocarcinoma diagnosed from 2006 to 2009 in Clinical Hospital Center Split, Croatia, were analysed. Clinical data were collected from the Pulmology Department and time of death from the Mortality Registry. Paraffin blocks of bronchoscopic biopsies were collected from the Institute of Pathology and 15 cases excluded from the analysis due to insufficient material. Expression of IMP3, Napsin A and TTF-1 were analysed by indirect enzyme immunohistochemistry. Statistical analysis was performed and $P$ values less than 0.05 considered significant.

Results: Of 90 patients, 71 (78\%) were males and 19 (22\%) females. Median age for males was 61.5 years (min-max 43-83) and for females 61 years (min-max 44-86). Pleural effusion was found in 15 (16.6\%) and distant metastases in $45(50 \%)$ cases. According to histological subtypes, there were 34 acinar, 2 lepidic, 2 papillary and 52 solid subtypes. IMP3 overexpression was found in 63 cases $(70 \%)$ and was correlated with solid subtype $(P=0.002)$ and negative/weak Napsin A expression $(P=0.004)$. Strong Napsin A expression correlated with TTF-1 expression $(P=0.003)$ and lower histological grades $(P=0.031)$. Patients with IMP3 overexpression more often had distant metastases than patients with negative IMP3, 55.5\% versus 33.3\% ( $P=0.033)$. Non solid subtypes with IMP3 overexpression developed distant metastasis more common than non solid subtypes with negative IMP3, $72 \%$ versus $35 \%(P=0.028)$.

Conclusions: Expression of IMP3 correlates with solid subtype and with distant metastases regardless of histological subtype of lung adenocarcinoma.

Virtual slides: http://www.diagnosticpathology.diagnomx.eu/vs/1966211581795258

\footnotetext{
* Correspondence: merigdst@yahoo.co.uk

${ }^{1}$ Institute for pathology, forensic medicine and cytology Clinical Hospital

Center Split, Split, Croatia

Full list of author information is available at the end of the article
}

\section{Biomed Central}

(c) 2012 Beljan Perak et al.; licensee BioMed Central Ltd. This is an Open Access article distributed under the terms of the Creative Commons Attribution License (http://creativecommons.org/licenses/by/2.0), which permits unrestricted use, distribution, and reproduction in any medium, provided the original work is properly cited. 


\section{Zusammenfassung}

Hintergrund: Das Lungenkarzinom kommt meistens als nicht resektabler Tumor vor und die Diagnose kann nur in kleinen Biopsaten oder zytologisch gestellt werden. In der Gruppe der nicht kleinzelligen Lungenkarzinome kann der nicht anders spezifizierte Adenokarzinom Phänotyp mit Hilfe der Antikörper TTF-1 und Napsin A diagnostiziert werden. Die Expression des onkoföetalen Proteins IMP3 ist bei humanen Karzinomen mit agressivem Verhalten und metastatischem Potential verbunden. In dieser Studie korreliert die Expression von IMP3 mit TTF-1, Napsin A, histologischem Typ und klinischem Staging des Lungenkarzinoms. Wir waren daran interessiert, ob Fernmetastasen mit IMP3 Überexpression assoziiert sind, unabhängig von der histologischen Subtyp von Adenokarzinom.

Methode: In der retrospektiven Studie wurden die von 2006 bis 2009 im Klinischem Krankenhaus Split, Kroatien diagnostizerte Adenokarzinome der Lunge von 105 Patienten analysiert. Die klinischen Daten stammten aus der Abteilung für Pulmologie und im Falle des Todes vom Todesregister. Die Paraffinblöcke der primären Lungenbiopsate dieser Patienten wurden im Institut für Pathologie mit der indirekter Enzym - Immunohistochemie mittels Kombination der Antikörper gegen IMP3, Napsin A und TTF1 untersucht. 15 Fälle aus der Analyse aufgrund unzureichender Material ausgeschlossen. Es wurde eine statistische Untersuchung durchgeführt und Werte weniger als $0.05 P$ wurden als statistisch signifikant bezeichnet.

Ergebnisse: Von 90 Patienten mit Lungencarcinom waren 71 (78\%) mänlich, durchschnittliches Alter war für Männer 61.5 Jahre (min-max 43-83) und 61 Jahre für Frauen (min-max 44-86). Pleurale Effusionen fand man in 15 Fällen (16.6\%) und Fernmetastasen in 45 (50\%) Fällen. Histologische Sybtypen waren: 2 lepidic Karzinome, 34 azinäre Karzinome, 2 papilläre und 52 solide Karzinome. IMP3 war exprimiert in 63 Fälle (70\%). Positive IMP3 Expression war mit solidem Typ $(P=0.002)$ und negativer Napsin A Expression $(P=0.004)$ assoziert. Napsin A Expression war mit niedrigem Gradus $(P=0.031)$ und positiver TTF-1 Expression $(P=0.003)$ assoziert. Patienten mit IMP3 Überexpression öfter hatten Fernmetastasen als Patienten mit negativen IMP3, 55.5\% versus 33.3\% ( $P=0.033)$. Non solide Subtyp mit IMP3 Überexpression entwickelten Fernmetastasen Meer häufiger als nicht festem Subtyp mit negativen IMP3, $72 \%$ versus 35\% ( $P=0.028)$.

Schlussworte: Die Expression von IMP3 ist mit negaativer Expression von Napsin A, solidem Subtyp und Metastasen verbunden und hat praktische predictive Werte in der pathologischen Diagnose des Adenokarzinoms der Lunge. Die Expression von IMP3 korreliert mit soliden Subtyp und mit Fernmetastasen unabhängig von histologische Subtyp Lungenadenokarzinom.

Keywords: Lung adenocarcinoma, Aggressive phenotype, TTF-1, Napsin A, IMP-3

\section{Background}

Lung cancer is the leading cause of cancer mortality in the world, with the highest incidence in the Western World and poor overall survival [1]. It presents a complex disease with different phenotypes, variabile responses to therapy and probably different relationships to specific carcinogens [2]. Small cell lung carcinomas (SCLC) and non-small cell lung carcinomas (NSCLC) are wide and clinically relevant groups of lung cancer. The most common histologic type of NSCLC is adenocarcinoma (ADC), accounting for nearly half of all lung cancers [3]. There is general agreement that squamous cell carcinoma (SCC) and SCLC have the highest accuracy of diagnosis in small preoperative specimens, whereas ADC is less accurately diagnosed due to its histological complexity [4]. Due to advanced clinical stage at presentation, up to $90 \%$ of diagnoses are established on small biopsy or cytology specimen [5], but because of the paucity of bronchoscopic material, careful selection of ancillary methods (like histochemical mucin stain, immunohistochemistry and polymerase chain reaction) should be done [6]. Multiplex panel dual immunohistochemistry using p63/CK 5 and TTF-1/Napsin A are useful in subcategorising NSCLC-NOS into SCC and ADC phenotypes [7]. Combination of TTF-1 and Napsin A highly improved sensitivity and specificity for diagnosing lung adenocarcinoma [8]. TTF-1 is a nuclear tissue-specific DNA-binding protein mainly expressed in thyroid follicular cells, type II pneumocytes and nonciliated bronchiolar epithelial cells. Its function in lungs is transcriptional activation of surfactant proteins and secretory proteins of Clara cells [9]. Napsin A is aspartic proteinase involved in the maturation of the surfactant B. It is expressed in the cytoplasm of type II pneumocytes and Clara cells, in proximal tubular renal epithelium and exocrine pancreas [10,11]. In the last few years IMP3, member of insulin-like growth factor II mRNA binding protein family, was investigated in different malignant neoplasms because its overexpression is generally associated with aggressive and advanced tumours [12]. Normally, IMP3 is expressed in developing tissues during embryogenesis and plays the role in 
RNA trafficking and stabilisation, cell growth and migration [13]. In adult tissues IMP3 expression is low or undetectable, but in malignant tumors is strongly expressed $[14,15]$. In most studies increased expression of IMP3 correlates with aggressive biological behaviour of the tumour [16,17]. Expression of IMP3 in series of lung cancer was analysed in few studies. According to these articles, IMP3 overexpression in high grade neuroendocrine carcinoma [18], non small cell lung carcinoma [19] and adenocarcinoma [20] correlated with poor differentiation and advanced stage of disease. In this study we analysed expression of IMP3 in histological subtypes of lung adenocarcinoma and its impact on clinical staging.

\section{Methods}

From January 2006 till December 2009, 807 new cases of lung cancer were diagnosed at the Institute of pathology, forensic medicine and cytology, Clinical Hospital Center Split, Croatia. The consecutive series of 105 patients with primary inoperable adenocarcinoma were investigated. Clinical data (age, sex, tumor size, clinical staging) were collected from the hospital records and time of death from the Mortality Registry. Overall survival was evaluated for outcome analysis. Paraffin blocks were collected from the Institute of pathology, forensic medicine and cytology and 15 cases were excluded due to insufficient material. Indirect immunohistochemical analysis was performed on $5-\mu \mathrm{m}$ sections using primary monoclonal mouse antibodies against IMP3 (dilution 1:200), Napsin A (dilution 1:200) and TTF-1 (dilution 1:100), EnVision/HRP and chromogen 3,3'-diaminobenzidine (all reagents DAKO, Glostrup, Denmark). The slides were analysed with light microscope Olympus 51BX by two pathologists. Diffuse cytoplasmic staining for IMP3, nuclear staining for TTF-1 and granular cytoplasmic staining for Napsin A were considered positive. Expression of TTF-1 and IMP3 was assessed as positive or negative and expression of Napsin A as negative/weak or strongly positive (Figure 1). Cases with more than $10 \%$ of positive cells were considered as positive. Statistical analysis was performed using the SPSS 19 system for Windows and $P$ value less than 0.05 was considered statistically significant.

\section{Results}

In the sample were 90 patients, 71 (78\%) males and 19 $(22 \%)$ females. Median age for males was 61.5 years (minmax 43-83) and for females 61 years (min-max 44-86). In five years of follow up, 79 (87\%) patients died. The mean overall survival was 8 months (95\% CI 1-34 months). Median survival was 2,5 times longer in patients without distant metastases: 9 months (SE 1.8 months) (95\% CI 5.4-12.6) compared to patients with metastases: 4 months (SE 1.1) (95\% CI 1.9-6.1) (log rank $6.5 \mathrm{P}=0.011)$. The pleural effusion was present in $15(16.6 \%)$ cases and in 14 patients was cytologically malignant. In the beginning of diagnostic procedure 19 patients were examined with

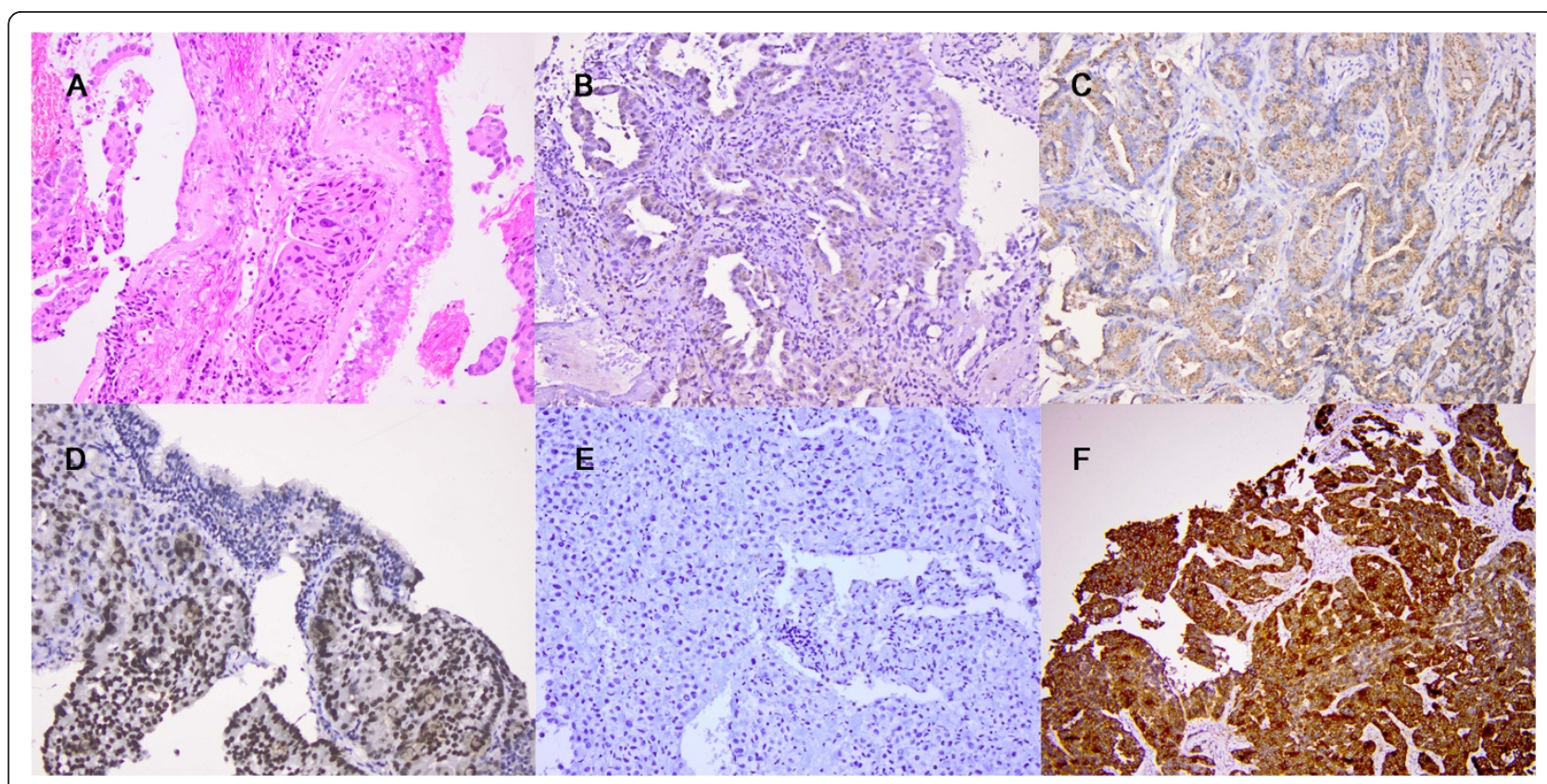

Figure 1 Expression of TTF-1, Napsin A and IMP3 in lung adenocarcinoma. A Tumor tissue infiltrates bronchal mucosa, B Nuclei of malignant cells are positive to TTF-1, C Weak cytoplasmatic granular positivity to Napsin A. D Strong granular cytoplasmatic positivity to Napsin A. E Negative expression od IMP3, F positive expression of IMP3 (200x). 
multislice computed tomography of the thorax and upper abdomen and staged into T2 (5), T3 (7) and T4 (7) categories; the remaining patients only had chest radiography. Median tumour size was $58.5 \mathrm{~mm}$ (min-max 21112). Radiographic evidence of significantly enlarged and presumably positive regional lymph nodes had 51 (56.6\%) patients. In the analysed period $45(50 \%)$ patients developed distant metastases in bones (14), brain (10), liver (5), adrenal glands (4), or multiple sites (12). Histological grading was performed according to the presence of solid component and cytological atypia [21], resulting in 18 well differentiated, 23 moderately differentiated and 49 poorly differentiated tumours. According to the criteria set forth by the WHO (2004), there were 34 acinar, 2 lepidic, 2 papillary and 52 solid subtypes; in further analysis solid subtype has been compared to others.

According to Table 1, positive expression of IMP3 was found in $61(67.7 \%)$ cases. Median age of patients with positive IMP3 expression was 58.5 years (min-max 4383) and of patients with negative IMP3 expression 63 years $(53-79)(Z=1,75 P=0.08)$. Median tumor size was $58.5 \mathrm{~mm}$ (min-max 21-112) in IMP3 positive patients and $60 \mathrm{~mm}$ (min-max 22-108) in IMP3 negative patients $(Z=0.82 \quad P=0.411)$. No statistically significant correlations were observed with sex $\left(\chi^{2}=0156 P=0.693\right)$, pleural effusion $\left(\chi^{2}=3.5 P=0.063\right)$, histological grade $\left(\chi^{2}=\right.$ $2.499 P=0.287)$ and TTF-1 expression $\left(\chi^{2}=0.276 P=\right.$ 0.599). Overexpression of IMP3 correlates to solid subtype $\left(\chi^{2}=9.4 P=0.002\right)$ and negative Napsin A expression $\left(\chi^{2}=8.25 P=0.004\right)$. In the group of 52 cases with solid subtype, $43(82.6 \%)$ had IMP3 overexpression and in the group of 38 cases with other subtypes 20 (52.6\%). IMP3 overexpression correlated with presence of distal metastases (staging M1b) $\left(\chi^{2}=6.844 P=0.033\right)$.

Table 2 shows the distribution of metastases according to IMP3 overexpression in patients with non solid subtype of adenocarcinoma. Among 18 patients with distant metastases, $13(72 \%)$ were IMP3 positive. Among 20 patients without distant metastases, IMP3 was positive in 7 (35\%) cases. In non solid subtypes, IMP3 overexpression was more often found in patients who developed metastasis (Fisher exact test $P=0.028$ ). IMP3 positive cases had shorter time of overall survival, but result is not statistically significant (log rank 0.14 $P=$ 0.713). Patients with negative IMP3 expression had mean survival 9 months (SE 2 months) (95\% CI 512 months) and patients with positive IMP3 had mean survival 9 months (SE 1 month) (95\% CI 4-6 months).

Expression of Napsin A was not related to sex $\left(\chi^{2}=1.577\right.$ $P=0.209)$ and pleural effusion $\left(\chi^{2}=0 P=1\right)$. In cases with

Table 1 Expression of IMP3 in patients with lung adenocarcinoma

\begin{tabular}{|c|c|c|c|c|c|}
\hline \multirow[t]{2}{*}{ Variable } & & \multirow[t]{2}{*}{$\mathbf{N}$} & \multicolumn{2}{|c|}{ IMP3 $(\mathrm{N}=90)$} & \multirow[t]{2}{*}{$P$} \\
\hline & & & Negative N (\%) & Positive N (\%) & \\
\hline \multirow[t]{3}{*}{ Gradus } & 1 & 18 & $8(29.6)$ & $10(15)$ & 0.287 \\
\hline & 2 & 23 & $7(25.9)$ & $16(25)$ & \\
\hline & 3 & 49 & $12(44)$ & $37(58)$ & \\
\hline \multirow[t]{2}{*}{ Subtype } & solid & 52 & $9(33)$ & $43(68)$ & 0.002 \\
\hline & others & 38 & $18(66)$ & $20(31)$ & \\
\hline \multirow[t]{2}{*}{ Napsin A } & negative/light & 60 & $12(46)$ & $48(77)$ & 0.004 \\
\hline & strong positive & 28 & $14(53)$ & $14(22)$ & \\
\hline \multirow[t]{2}{*}{ TTF-1 } & negative & 31 & $9(33.3)$ & $22(39.2)$ & 0.599 \\
\hline & positive & 52 & $18(66.6)$ & $34(60.7)$ & \\
\hline \multirow[t]{2}{*}{ Pleural effusion } & no & 29 & $6(42.8)$ & $3(76.6)$ & 0.063 \\
\hline & yes & 15 & $8(16.6)$ & $7(23.3)$ & \\
\hline \multirow[t]{3}{*}{ T staging } & 2 & 10 & $4(33.3)$ & $6(21.4)$ & 0.458 \\
\hline & 3 & 10 & $2(16.6)$ & $8(28.5)$ & \\
\hline & 4 & 20 & $6(50)$ & $14(50)$ & \\
\hline \multirow[t]{3}{*}{ N staging } & 1 & 20 & $9(64)$ & $11(52.3)$ & 0.612 \\
\hline & 2 & 14 & $5(35)$ & $9(42.8)$ & \\
\hline & 3 & 1 & 0 & $1(4)$ & \\
\hline \multirow[t]{3}{*}{ M staging } & 0 & 31 & $10(37)$ & $22(34.9)$ & 0.033 \\
\hline & $1 \mathrm{a}$ & 14 & $8(29.6)$ & $6(9.5)$ & \\
\hline & $1 \mathrm{~b}$ & 45 & $9(33.3)$ & 36 (55.5) & \\
\hline
\end{tabular}

$\overline{x^{2} \text { test. }}$ 
Table 2 IMP3 in non solid subtypes of lung adenocarcinoma and distant metastasis

\begin{tabular}{lllll}
\hline Non solid subtypes $(\mathbf{N}=\mathbf{3 8})$ & \multicolumn{2}{c}{ IMP3 } & Distal metastasis \\
\cline { 2 - 4 } & negative & positive & \\
\hline 18 & $5(27.7)$ & $13(72.2)$ & yes \\
20 & $13(65)$ & $7(35)$ & no \\
\hline
\end{tabular}

Fisher exact test.

negative expression of Napsin A median tumor size was $59 \mathrm{~mm}$ (min-max 23-112) and with positive Napsin A expression $59.98 \mathrm{~mm}$ (min-max 21-108) $(\mathrm{Z}=0.518 \quad P=$ 0.605). Napsin A expression correlated with TTF-1 positivity $\left(\chi^{2}=8.986 P=0.003\right)$ and lower histological grade $\left(\chi^{2}=8.986 P=0.003\right)$.

\section{Discussion}

About $70-80 \%$ of lung carcinomas fall under the classification of NSCLC with adenocarcinoma as the most common subtype [22]. In the past, all subtypes of NSCLC received the same therapy and subclassification was not important for the treatment or prognosis. Recent development in the treatment strategies necessitates further cytological and histological subtyping of NSCLC. Promotor methylation was more common find in squamous carcinoma and correlated to pleural indentation [23]. Activated gene mutations are more common found in adenocarcinoma [2]. New biologically targeted chemotherapies, such as bevacizumab, have clinical benefits in patients with $\mathrm{ADC}$, but strong contraindications in SCC cases. There are therapies that target EGFR mutations and ALK fusion genes which are found almost exclusively in adenocarcinomas. Architecture of pulmonary adenocarcinoma is very heterogeneous. Morphologic features, as specified in the WHO classification 2004, have been the standard for NSCLC subtyping, but according to Terry et al. [7], 25\% of bronchoscopic biopsies cannot be subclassified by morphology alone so immunohistochemical and/or genetic analyses are necessary. Immunohistochemical markers TTF-1 and Napsin A are nowadays a useful tool in adenocarcinoma identification and their dual use improves diagnostic accuracy, but does not give us data about prognosis of cancer which often has high metastatic potential. There have been some studies about prognostic value of some histological characteristics $[9,21]$ or methylation markers [23]. We tried to obtain this important prognostic information using antibody to oncofetal protein IMP3, previously identified as a marker of aggressive behaviour in various tumours.

Expression of IMP3 was analysed in relation with histological grade proposed by Barletta et al. [21], but no significant correlation was found $(P=0.287)$. According to some authors, [24] there is no well-established histological or cytological grading scheme for NSCLC and currently applied subjective grading is not prognostically relevant. In our series solid subtype was the most common and it was analysed in relation to other subtypes (acinar, lepidic and papillary) grouped together. One case of papillary subtype had characteristics of recently described stromal micropapillary pattern [25,26]. IMP3 overexpression correlated with solid subtype $(P=0.002)$. In the series of 89 surgically resected specimens FindeisHosey et al. have found that positive IMP3 expression was strongly correlated with poorly differentiated adenocarcinoma and solid component of myxed subtype adenocarcinoma [20]. In our study, expression of TTF-1 and Napsin A were $61 \%$ and $51 \%$, respectively. TTF-1 expression value was within reported range [9], but percentage of Napsin A positive cases was surprisingly low [27]. Possible explanation for this could be high proportion of solid subtype in our series, although technical problems in sampling and fixation could not be excluded. Expression of Napsin negatively correlated with poor differentiation and 40 (76.9\%) cases of histologic grade 3 were Napsin A negative $(P=0.031)$. Expression of TTF-1 did not correlate with grade $(P=0.542)$, which confirmed objection of Ueno et al. [27] that TTF-1 showed no association with the grade of tumour differentiation. Both TTF-1 and Napsin A were negative in 28 cases, majority of those were of solid subtype and immunohistochemically negative to Cytokeratin $5 / 6$. The proportion of dual negative cases in our study was higher than in study of Turner et al. [8], 32\% versus $10.6 \%$, respectively which could be explained by high percentage of solid subtype in our sample. IMP3 overexpression correlated with negative expression of Napsin A $(P=$ 0.004), but correlation of IMP3 and TTF-1 was not found $(P=0.599)$.

During five-year follow-up, out of 90 patients with inoperable lung adenocarcinoma, 79 (8.77\%) died. The mean overall survival was 8 months $(95 \%$ CI 1-34 months). IMP3 overexpression had no influence on mean overall survival $(P=0.712)$. We did not find statistically significant difference in tumour size $(P=0.411)$, $\mathrm{T}$ staging $(P=0.458)$ or $\mathrm{N}$ staging $(P=0.612)$ among IMP3 overexpressed and IMP3 negative cases. FindeisHosey et al. found that IMP3 is more frequently expressed in larger tumours with positive lymph nodes or higher clinical stage, but the difference was not statistically significant [20]. 
In our series, 45 patients developed distant metastasis to the brain, liver, adrenal glands, bones or to multiple sites. Quite often symptoms of metastases were the first sign of the malignancy. IMP3 overexpression showed correlation with distant metastases regardless of histological subtype $(P=0.033)$. Further series are needed to confirm these results and eventually establish IMP3 in initial immunohistochemical panel for small bronchoscopic biopsy/cytology, as a marker for aggressive behaviour and higher metastatic potential of lung adenocarcinoma.

In conclusion, IMP3 overexpression correlated with solid subtype and negative expression of Napsin A, as well as distant metastasis regardless of hystological subtype. Our results confirm that positive IMP 3 expression predicts aggressive tumour behaviour in lung adenocarcinoma and can be used as a significant predictor of unfavorable outcome.

\section{Competing interests}

The authors declare that they have no competing interests.

\section{Authors' contributions}

RBP and MGD designed the study, analysed histological slides, interpreted the results and drafted the manuscript, AP, VI and MP collected pathological, clinical and radiological data, VC performed the statistical analysis and VS critically revised manuscript. All authors read and approved the final manuscript.

\section{Acknowledgements}

We thank mr. sc. dr. Zerina Jasarevic who translated the abstract to German language.

\section{Author details \\ ${ }^{1}$ Institute for pathology, forensic medicine and cytology Clinical Hospital Center Split, Split, Croatia. ${ }^{2}$ Department for nuclear medicine, Clinical Hospital Center Split, Split, Croatia. ${ }^{3}$ Pulmology Department Clinical Hospital Center Split, Split, Croatia. ${ }^{4}$ Institute for pathology, forensic medicine and cytology, University Hospital Mostar, Mostar, Bosnia and Herzegovina. ${ }^{5}$ Institute for radiology Clinical Hospital Center Split, Split, Croatia.}

Received: 28 August 2012 Accepted: 25 November 2012 Published: 28 November 2012

\section{References}

1. Kerr KM: Classification of lung cancer: proposals for change? Arch Pathol Lab Med 2012, 136:1190-1193.

2. Gabrielson E: Worldwide trends in lung cancer pathology. Respirology 2006, 11:533-538.

3. Travis WD, Brambilla E, Noguchi M, Nicholson AG, Geisinger KR, Yatabe $Y$, Beer DG, Powell CA, Riely GJ, Van Schil PE, Garg K, Austin JH, Asamura H, Rusch WW, Hirsch FR, Scagliotti G, Mitsudomi T, Huber RM, Ishikawa Y, Jett J, Sanchez-Cespedes M, Sculier JP, Takahashi T, Tsuboi M, Vansteenkiste J, Wistuba I, Yang PC, Aberle D, Brambilla C, Flieder D, et al: International association for the study of lung cancer/american thoracic society/ european respiratory society international multidisciplinary classification of lung adenocarcinoma. J Thorac Oncol 2011, 6:244-285.

4. Edvards SL, Roberts C, McKean ME, Cockburn JS, Jeffrey RR, Kerr KM: Preoperative histological classification of primary lung cancer: accuracy of diagnosis and use of the non-small cell category. J Clin Pathol 2000, 53:537-540

5. Travis WD, Rekhtman N, Riley GJ, Geisinger KR, Asamura H, Brambilla E, Garg K, Hirsch FR, Noguchi M, Powell CA, Rusch WW, Scagliotti G, Yatabe Y: Pathologic diagnosis of advanced lung cancer based on small biopsies and cytology: a paradigm shift. J Thorac Oncol 2010, 5:411-414.
6. Jagirdar J: Application of immunohistochemistry to the diagnosis of primary and metastatic carcinoma to the lung. Arch Pathol Lab Med 2008, 132:384-396.

7. Terry J, Leung S, Laskin J, Leslie KO, Gown AM, lonescu DN: Optimal immunohistochemical markers for distinguishing lung adenocarcinomas from squamous cell carcinomas in small tumor samples. Am J Surg Pathol 2010, 34:1805-1811.

8. Turner BM, Cagle PT, Sainz IM, Fukuoka J, Shen SS, Jagirdar J: Napsin A, a new marker for lung adenocarcinoma, is complementary and more sensitive and specific than thyroid transcription factor 1 in the differential diagnosis of primary pulmonary carcinoma: evaluation of 1674 cases by tissue microarray. Arch Pathol Lab Med 2012, 136:163-171.

9. Barletta JA, Perner S, lafrate AJ, Yeap BY, Weir BA, Johnson LA, Johnson BE, Meyerson M, Rubin MA, Travis WD, Loda M, Chirieac LR: Clinical significance of TTF-1 protein expression and TTF-1 gene amplification in lung adenocarcinoma. J Cell Mol Med 2009, 13:1977-1986.

10. Stoll LM, Johnson MW, Gabrielson E, Askin F, Clark DP, Li QK: The utility of napsin- $A$ in the identification of primary and metastatic lung adenocarcinoma among cytologically poorly differentiated carcinomas. Cancer Cytopathol 2010, 118:441-449.

11. Bishop JA, Sharma R, Illei PB: Napsin A and thyroid transcription factor-1 expression in carcinomas of the lung, breast, pancreas, colon, kidney, thyroid, and malignant mesothelioma. Hum Pathol 2010, 41:20-25.

12. Findeis-Hosey J, $\mathrm{Xu} \mathrm{H}$ : The use of insulin like-growth factor II messenger RNA binding protein-3 in diagnostic pathology. Hum Pathol 2011, 42:303-314.

13. Mueller-Pillasch F, Lacher U, Wallrapp C, Micha A, Zimmerhackl F, Hameister $H$, Varga G, Friess H, Buchler M, Beger HG, Vila MR, Adler G, Gress TM: Cloning a gene highly overexpressed in cancer coding for a novel KH-domain containing protein. Oncogene 1997, 14:2729-2733.

14. King RL, Pasha T, Roullet MR, Zhang PJ, Bagg A: IMP-3 is differentially expressed in normal and neoplastic lymphoid tissue. Hum Pathol 2009, 40:1699-1705.

15. Lu D, Yang $X$, Jiiang NY, Woda BA, Liu Q, Dresser K, Mercurio AM, Rock KL, Jiang Z: IMP3, a new biomarker to predict progression of cervical intraepithelial neoplasia into invasive cancer. Am J Surg Pathol 2011, 35:1638-1645.

16. Jiang Z, Chu PG, Woda BA, Rock KL, Liu O, Hsieh CC, Chen W, Duan HO, McDougal S, Wu CL: Analysis of RNA-binding protein IMP3 to predict metastasis and prognosis of renal-cell carcinoma:a retrospective study. Lancet Oncol 2006, 7:556-564.

17. Wang $L, L i ~ H, X i a ~ Z, L u J$, Peng T: IMP3 is a novel biomarker to predict metastasis et progosis of gastric adenocarcinoma; a retrospective study. Chin Med J 2010, 123:3554-3558.

18. Xu H, Bourne PA, Spaulding BO, Wang HL: High-grade neuroendocrine carcinomas oft he lung express $\mathrm{K}$ homology domain containing protein overexpressed in cancer but carcinoid tumors do not. Hum Pathol 2007, 38:555-563.

19. Belleza G, Cavaliere A, Sidoni A: IMP3 expression in non-small cell lung cancer. Hum Pathol 2009, 40:1205-1206.

20. Findeis-Hosey JJ, Yang Q, Spaulding BO, Wang HL, Xu H: IMP3 expression is correlated with histologic grade of lung adenocarcinoma. Hum Pathol 2010, 41:477-484.

21. Barletta JA, Yeap BY, Chirieac LR: Prognostic significance of grading in lung adenocarcinoma. Cancer 2010, 116:659-669.

22. Charloux A, Quoix E, Wolkove N, Small D, Pauli G, Kreisman H: Increasing incidence of lung adenocarcinoma: reality or artefact? A review of the epidemiology of lung adenocarcinoma. Int J Epidemiol 1997, 26:14-23.

23. Ji M, Zhang Y, Shi B, Hou P: Association of promoter methylation with histologic type and pleural indentation in non-small cell lung cancer (NSCLC). Diagn Pathol 2011, 6:48.

24. Sterlacci W, Savic S, Schmid T, Oberaigner W, Auberger J, Fiegl M, Tzankov A: Tissue-sparing application of the newly proposed IASLC/ATS/ERS classification of adenocarcinoma of the lung ahows practical diagnostic and prognostic impact. Am J Clin Pathol 2012, 137:946-956.

25. Ohe M, Yokose T, Sakuma Y, Osanai S, Hasegawa C, Washimi K, Nawa K, Woo T, Hamanaka R, Nakayama H, Kameda Y, Yamada K, Isobe T: Stromal micropapillary pattern predominant lung adenocarcinoma - a report of two cases. Diagn Pathol 2011, 6:92. 
26. Ohe M, Yokose T, Sakuma Y, Miyagi Y, Okamoto N, Osanai S, Hasegawa C, Nakayama H, Kameda Y, Yamada K, Isobe T: Stromal micropapillary component as a novel unfavorable prognostic factor of lung adenocarcinoma. Diagn Pathol 2012, 7:3.

27. Ueno $T$, Linder $S$, Elmberger $G$ : Aspartic proteinase napsin is a useful marker for diagnosis of primary lung adenocarcinoma. British I Cancer 2003, 88:1229-1233.

doi:10.1186/1746-1596-7-165

Cite this article as: Beljan Perak et al:: IMP3 can predict aggressive

behaviour of lung adenocarcinoma. Diagnostic Pathology 2012 7:165.

\section{Submit your next manuscript to BioMed Central and take full advantage of:}

- Convenient online submission

- Thorough peer review

- No space constraints or color figure charges

- Immediate publication on acceptance

- Inclusion in PubMed, CAS, Scopus and Google Scholar

- Research which is freely available for redistribution 